\title{
POTENSI PRODUK MIMBA (Azadirachta indica A. Juss) DAN FAKTOR-FAKTOR YANG MEMPENGARUHI POTENSI DAUN MIMBA DI LOMBOK
}

\author{
(The Potency of Neem (Azadirachta indica A. Juss) Product and \\ Factors affecting The Neem Leaf Production in Lombok)
}

\author{
I Wayan Widhiana Susila ${ }^{1}$ \\ ${ }^{1}$ Balai Penelitian dan Pengembangan Teknologi Hasil Hutan Bukan Kayu \\ Badan Litbang dan Inovasi, Kementerian Lingkungan Hidup dan Kehutanan \\ Jl. Darma Bakti No 7 Ds. Langko Kecamatan Lingsar, Kabupaten Lombok Barat \\ Email : widhianasusila@gmail.com
}

\begin{abstract}
Neem (Azadirachta indica A. Juss) is a type of non-timber forest product, the leaves could produce plant-based for bio-pesticides and antiseptics. This study aimed to obtain information on potential stands, leaf production and its oil content and the factors that affecting the neem leaf potency. Research was done purposively by the surveying method and tree measurements was census in each location. The neem leaf potency per tree in East Lombok is 7.4 to $21.6 \mathrm{~kg}$, oil content and rendement is 0.07 to $0.20 \mathrm{~kg}$ and 1.88 to $2.33 \%$. North Lombok are, 8.5 to $21.2 \mathrm{~kg}$ for potential leaf, and 0.14 to 0.18 $\mathrm{kg}$ for oil content and 2.17 to $4.34 \%$ for ist oil rendement. Neem leaf production is influenced by branches and sub number, diameter and crown width, while a site less influential (elevation and soil $p H)$. The parameter use of sub-branches number to get the best model to estimate the potential of leaves, good for one or more variables. The use of all the identified variables (diameter, pertajukan, and a place to grow), obtained $48.9 \%$ R-square. Means more than $50 \%$ of other variables that have not been identified that affect the potential of neem leaves.
\end{abstract}

Keywords : Neem (Azadirachta indica A. Juss), leaf, East Lombok, North Lombok

\begin{abstract}
ABSTRAK
Mimba (Azadirachta indica A. Juss) merupakan jenis hasil hutan bukan kayu (HHBK) yang produk daunnya sebagai penghasil bahan pestisida nabati dan antiseptik. Keberadaan mimba cukup potensial di Lombok yang tumbuh alami di lahan-lahan kering. Penelitian ini bertujuan untuk memperoleh informasi potensi biomassa daun dan kandungan minyaknya serta faktor-faktor yang mempengaruhi potensi daun mimba. Penelitian dilakukan secara purposive dengan metode survai dan pengukuran dimensi pohon secara sensus pada setiap lokasi. Potensi daun mimba per pohon di Lombok Timur adalah 7,4-21,6 kg, kandungan minyak dan rendemennya 0,07 - 0,20 kg dan 1,88$2,33 \%$. Di Lombok Utara potensi daun, kandungan minyak dan rendemennya adalah $8,5-21,2 \mathrm{~kg}$ per pohon, $0,14-0,18 \mathrm{~kg}$ per pohon dan $2,17-4,34 \%$. Stok biomassa daun mimba per kecamatan adalah Jerowaru 0,31 ton, Keruak 0,31 ton, Sakra 0,32 ton, Pringgabaya 0,13 ton, Sambelia 0,13 ton dan Kecamatan Bayan 0,69 ton. Produksi daun mimba sangat dipengaruhi oleh jumlah ranting, jumlah cabang, diameter dan lebar tajuk pohon, sedangkan faktor tempat tumbuh kurang berpengaruh (elevasi dan $\mathrm{pH}$ tanah). Penggunaan parameter jumlah ranting mendapatkan model terbaik untuk menduga potensi daun, baik untuk satu variabel maupun lebih. Penggunaan semua variabel yang teridentifikasi tersebut (diameter, pertajukan, dan tempat tumbuh), diperoleh $R$-square 48,9\%. Berarti lebih dari 50\% variabel lain yang belum teridentifikasi yang berpengaruh terhadap potensi daun mimba.
\end{abstract}

Kata kunci : Mimba (Azadirachta indica A. Juss), daun, Lombok Timur, Lombok Utara 


\section{PENDAHULUAN}

Mimba (Azadirachta indica A. Juss) merupakan jenis tumbuhan hutan yang dapat menghasilkan produk kayu dan bukan kayu yaitu daun. Daun mimba digunakan sebagai bahan baku pestisida nabati dan zat antiseptik (obat-obatan) yang dihasilkan dari minyak mimba hasil ekstraksi daun mimba. Produk lain dari daun mimba adalah neem leaves powder (tepung daun mimba) sebagai bahan obat dan insektisida, sudah beredar dipasaran yang diproduksi oleh PT Intaran Indonesia yang berkedudukan di Denpasar, Bali.

Sebaran tempat tumbuh mimba banyak dijumpai di sepanjang daerah kering pantai selatan dan utara Pulau Lombok. Potensi mimba cenderung mengalami penurunan karena penebangan. Sebagian besar kayunya digunakan sebagai bahan kayu bakar untuk usaha tembakau. Di wilayah NTB terjadi defisit kebutuhan kayu bangunan yang cukup tinggi, yakni 80.000 meter kubik per tahun sementara kebutuhan kayu bakar sekitar 480.000 m3/tahun (Dinas Kehutanan NTB, 2007). Kabupaten Lombok Timur sebagai salah satu daerah utama penyerap kayu bakar terbesar di NTB untuk pemenuhan sedikitnya 10.520 oven tembakau, dibutuhkan sedikitnya $370.045 \mathrm{~m} 3$ kayu bakar per tahun (Zaenal, 2007). Kondisi ini kemungkinan menjadi sebab berkurangnya pasokan bahan baku biji dan daun mimba dari Lombok untuk PT Intaran di Denpasar (Susila, Cakrawarsa, Handoko, 2014). Tidak perlu karena kurang berkorelasi dengan topik

Usaha produk mimba lokal dihadapkan pada permasalahan penurunan dan ketidakpastian suplai bahan baku dari NTB. Di samping itu, data dan informasi potensi produk tanaman mimba belum tersedia. Kondisi ini menyebabkan ketersediaan produksi minyak mimba sebagai suplay bahan baku obat-obatan belum bisa diprediksi sehingga usaha industri berbahan baku produk tanaman mimba akan menemui kendala. Belum adanya data kuantifikasi produk mimba terutama daunnya akan menjadi penghambat sebagai sumber stok bahan baku. Penekanan pada produk daun dalam penelitian ini karena stok bahan baku tersedia sepanjang tahun, sedangkan produk bijinya hanya $1-2$ bulan saja, yaitu sekitar Bulan Desember - Januari tahun berikutnya. Informasi ketersediaan dan keberlanjutan bahan baku merupakan kunci penting bagi keberhasilan pengusahaan mimba. Oleh karena itu, penelitian ini bertujuan untuk memperoleh informasi produksi biomassa daun dan minyak mimba, serta faktor-faktor yang berpengaruh terhadap potensi daun pada pohon mimba.

\section{BAHAN DAN METODE}

\section{A. Lokasi dan Waktu Penelitian}

Penelitian dilakukan pada lahan-lahan milik masyarakat di Pulau Lombok yang terdapat sebaran mimba. Penelitian dilaksanakan di Kabupaten Lombok Timur dan Lombok Utara, yaitu di :

- Kecamatan Jerowaru pada ketinggian 22-45 $\mathrm{m}$ dpl, lokasi Teong Elong, Kuburan Lis, Desa Serumbung dan di lahan milik SMP Negeri I Jerowaru

- Kecamatan Keruak pada ketinggian 13 - 17 $m$ dpl, lokasi lahan milik Balai Pengembangan dan Penangkapan Ikan Tanjung Luar dan Lahan milik SMK Keruak

- Kecamatan Sakra pada ketinggian 23-24 m dpl, lokasi lahan milik TNI Al Lombok Timur Desa Lepak Membe dan Desa Seliyat.

- Kecamatan Labuhan Haji pada ketinggian 56 -69m dpl, lokasi Ijobalit.

- Kecamatan Pringgabaya pada ketinggian 26 - 69m dpl, lokasi Dedalpak Poh Gading dan Bagek Pungguk.

- Kecamatan Sambelia pada ketinggian 17-45 m dpl, lokasi Pantai Gili Lampu dan Desa Sendanggalih.

Sedangkan di Lombok Utara, tersebar di wilayah :

- Di Kecamatan Bayan (Desa Anyar, Sukadana dan Desa Akar-Akar) pada ketinggian 11 - 97 m dpl.

- Kecamatan Gangga di Desa Montong, pada ketinggian $11-37 \mathrm{~m}$ dpl. 
- Kecamatan Pemenang di Desa Malaka,pada ketinggian 17 - $21 \mathrm{~m}$ dpl. Desa Anyar dilakukan di Dusun Greneng dan Grisak

- Desa Sukadana di Dusun Koloh Tantang, dan

- Desa Akar-akar di Dusun Batu Keruk

Penyulingan daun mimba untuk memperoleh data rendemen minyak dilakukan di Laboratorium Balai Penelitian Teknologi Hasil Hutan Bukan Kayu (BPTHHBK) di Desa Langko Kecamatan Lingsar Lombok Barat.

Waktu penelitian dari mulai survei potensi, pengumpulan biomassa daun sampai penyulingan ekstrak daun menghasilkan minyak mimba dilaksanakan pada bulan Maret s/d Desember 2013.

\section{B.Alat dan Bahan}

Alat dan bahan untuk pengamatan di lapangan yaitu GPS, hagameter, phiband, timbangan, meteran roll, kompas, tali tambang plastik, kamera, karung plastik, counter, tally sheet, label pohon, cat, kuas, tegakan mimba, ranting dan daun mimba. Alat dan bahan penunjang untuk penyulingan daun di laboratorium adalah aluminium voil, timbangan, seltif, kantong plastik, blender, aquadest, rak dan tabung reaksi, selang penyulingan, klem, statif stick, mesin pemanas, destilator dan kertas corong.

\section{Survai identitas dan Penentuan pohon model}

Pada setiap lokasi sebaran (desa atau dusun) dilakukan secara sensus pengamatan dan pengukuran tanaman mimba, yaitu diameter batang $(d b h)$ dan diameter tajuk terhadap pohon-pohon yang berdiameter sekitar $\geq 10 \mathrm{~cm}$.

Semua data pohon pada setiap lokasi dihimpun dalam kelompok klasifikasi diameter batang setinggi dada. Berdasarkan lokasi ditentukan pemilihan pohon model sesuai sebaran kelas diameter sebagai dasar untuk pengukuran selanjutnya (biomassa daun). Jumlah pohon model pada setiap kelas diameter ditentukan oleh sebaran populasi di lapangan dan dihitung berdasarkan cara Newman-Keul proportional (Alder, 1981 dalam Bustomi, Harbagung \& Suyat, 2005) yaitu :

$$
n i=(N i / N) * n
$$

Keterangan:

$N \quad=$ total jumlah pohon (populasi amatan);

$N i=$ jumlah pohon pada kelas parameter ke $i$ $(i: 1,2, d s t)$;

$n \quad=$ jumlah seluruh pohon model

Terhadap setiap pohon-pohon model tersebut dilakukan pengukuran dan pengamatan parameter-parameter sebagai berikut:

1) Tinggi pohon total (t_phn),

2) Tinggi pangkal tajuk (t_ptjk),

3) Jumlah cabang $\left(j_{-} c b\right)$,

4) Jumlah sub cabang/ranting $\left(j \_r t\right)$

5) Pengukuran elevasi (ketinggian dpl)

6) Pengambilan sampel tanah pada setiap lokasi tempat tumbuh mimba.

\section{Penandaan tajuk dan pengambilan daun}

Penandaan cabang/ranting tajuk pohon model dimaksudkan untuk persiapan pengambilan sampel daun mimba. Penimbangan daun kurang lebih $10-25 \%$ dari total daun (Bonner, Vozzo, Elam \& Land, 1994 dalam Nurhasybi \& Sudradjat, 2009). Penandaan tajuk untuk pengambilan daun dilakukan pada 2 cabang atau 3 - 4 ranting. Daun dari masing-masing cabang/ranting dipisahkan, kemudian ditimbang berat basahnya. Sampel daun disimpan dan dianginanginkan 4-7 hari untuk memperoleh berat kering udara, kemudian dilakukan penimbangan berat kering udara.

\section{Analisis produksi minyak mimba}

Sampel daun mimba kering udara dari setiap lokasi ditimbang seberat 100 gram untuk disuling. Daun diblender hingga lembut menyerupai ekstrak, ekstrak daun dicampur dengan air aquadest sebanyak 2 liter dan ditimbang. Kemudian dilakukan penyulingan selama 4 - 5 jam dengan suhu sekitar $30^{\circ} \mathrm{c}$. Prosedur penyulingan minyak mimba mengacu pada tata cara penyulingan minyak nilam oleh Anshori \& Hidayat (2009). Minyak mimba yang dihasilkan ditampung dan ditimbang beratnya. 


\section{Analisis Data}

\section{Potensi daun dan minyak mimba}

Berdasarkan hasil berat sampel daun pada setiap ranting atau cabang maka dapat dihitung potensi daun mimba per pohon (berat daun basah dan kering), yaitu:

- Berat basah total daun per pohon adalah jumlah ranting total dibagi jumlah ranting sampel dikalikan berat basah sampel

- Berat kering total daun per pohon adalah berat kering sampel dibagi berat basah sampel dikalikan berat basah total daun.

Produksi minyak dari daun mimba per pohon didekati melalui berat kering daun yang diekstrak, kemudian disuling menghasilkan berat minyak mimba. Potensi minyak per pohon dihitung dari perkalian berat kering total daun dengan berat minyak hasil sulingan dibagi dengan berat ekstrak sampel.

\section{HASILDAN PEMBAHASAN}

\section{A. Potensi Biomassa Daun Mimba}

Hasil pengamatan dan perhitungan parameter produksi daun pada setiap lokasi disajikan pada tabel Tabel 1 dan 2.

Tabel 1. Rata-rata berat biomassa daun mimba per pohon di Lombok Timur Table 1. Mean weight of neem leaf biomass per tree in East Lombok

\begin{tabular}{lrrrrrrr}
\hline $\begin{array}{c}\text { Lokasi } \\
(\text { Location })\end{array}$ & $\mathrm{N}$ & $\begin{array}{c}\text { Dbh } \\
(\mathrm{cm})\end{array}$ & $\begin{array}{c}\text { Dt } \\
(\mathrm{m})\end{array}$ & $\begin{array}{c}\text { BB sampel } \\
(\text { Sample }) \\
(\mathrm{g})\end{array}$ & $\begin{array}{c}\text { BB total } \\
(\mathrm{kg})\end{array}$ & $\begin{array}{c}\text { BK sampel } \\
(\text { Sample }) \\
(\mathrm{g})\end{array}$ & $\begin{array}{c}\text { BK total } \\
(\mathrm{kg})\end{array}$ \\
\hline Jerowaru & 9 & 24,6 & 7,5 & 721,7 & 21,57 & 315,6 & 9,18 \\
Keruak & 9 & 27,0 & 7,0 & 781,1 & 17,04 & 298,9 & 6,15 \\
Sakra & 23 & 23,0 & 10,4 & 541,7 & 9,06 & 267,8 & 4,39 \\
Pringgabaya & 10 & 21,5 & 5,4 & 502,2 & 8,39 & 225,6 & 3,70 \\
Sambelia & 10 & 24,9 & 6,1 & 385,0 & 7,41 & 202,0 & 3,80 \\
\hline Jumlah & $\mathbf{6 1}$ & $\mathbf{1 2 1}$ & $\mathbf{3 6 , 4}$ & $\mathbf{2 2 1 0}$ & $\mathbf{6 3 , 4 7}$ & $\mathbf{1 3 0 9 , 9}$ & $\mathbf{2 7 , 2}$ \\
\hline Rerata & $\mathbf{1 2 , 2}$ & $\mathbf{2 4 , 2}$ & $\mathbf{7 , 3}$ & $\mathbf{4 4 2 , 0}$ & $\mathbf{1 2 , 7}$ & $\mathbf{2 6 2 , 0}$ & $\mathbf{5 , 4}$ \\
\hline
\end{tabular}

Keterangan (Remark): $N=$ Jumlah pohon model(Sample number), Dbh = Diameter setinggi dada (Diameter at breast height), Dt = Diameter tajuk(Crown diameter), $B B=$ Berat basah (Wet weight), $B K=$ Berat kering (Dryweight), $d p l=$ Diatas permukaan laut (Above sealevel)

Pada Tabel 1 dapat dilihat bahwa tanaman mimba yang tumbuh di Kecamatan Jerowaru dan Keruak (saling berbatasan) merupakan penghasil daun yang relatif besar dibandingkan tanaman mimba dari lokasi lainnya. Tempat tumbuh mungkin berpengaruh atas perbedaan ini, karena rata-rata sebaran diameter di lima lokasi mimba yaitu di Kecamatan Jerowaru, Keruak, Sakra, Pringgabaya dan Kecamatan Sambelia relatif hampir sama (lihat Tabel 1). Tekstur tanah lokasi Jerowaru dan Keruak adalah liat lempung berpasir, dan lokasi lainnya bertekstur pasir (Lab. Tanah BPTPNTB, 2012). Tanah liat lempung berpasir relatif lebih subur dari pada tanah yang dominan pasir.

Rata-rata penyusutan berat daun dari berat basah ke berat kering udara adalah sebesar 180 gram (59,2\%). Lokasi pengeringan daun (kering udara) dilakukan di Kantor Balai Penelitian Teknologi Hasil Hutan Bukan Kayu pada ketinggian tempat kurang dari $100 \mathrm{~m}$ dpl. Penyusutan paling besar terjadi pada daun 
mimba yang berasal dari Kecamatan Keruak yaitu menurun sampai 482,2 gram. Perbedaan ini kemungkinan erat kaitannya dengan lokasi tempat pengeringan dan lokasi asal tanaman, yang salah satunya adalah perbedaan ketinggian lokasi. Semakin besar perbedaan ketinggian tempat tumbuh semakin besar terjadinya penyusutan. Lokasi mimba dari Keruak (13 - $17 \mathrm{mdpl})$, mempunyai perbedaan tinggi yang paling besar dengan tempat pengeringan $(<100 \mathrm{~m} \mathrm{dpl})$.

Tabel 1. Tabel 2. Rata-rata berat biomassa daun mimba per pohon di Lombok Utara Table 1. Mean weight of neem leaf biomass per tree in North Lombok

\begin{tabular}{lcccccrr}
\hline \multicolumn{1}{c}{$\begin{array}{c}\text { Lokasi } \\
(\text { Location })\end{array}$} & $\mathrm{N}$ & $\begin{array}{c}\text { Dbh } \\
(\mathrm{cm})\end{array}$ & $\begin{array}{c}\text { Dt } \\
(\mathrm{m})\end{array}$ & $\begin{array}{c}\text { BB sampel } \\
(\text { Sample })\end{array}$ & $\begin{array}{c}\text { BB total } \\
(\mathrm{kg})\end{array}$ & $\begin{array}{c}\text { BK sampel } \\
(\text { Sample }) \\
(\mathrm{g})\end{array}$ & $\begin{array}{c}\text { BK total } \\
(\mathrm{kg})\end{array}$ \\
\hline $\begin{array}{l}\text { Anyar, } \\
\text { Bayan }\end{array}$ & 26 & 17,7 & 4,5 & 907,3 & 8,85 & 355,0 & 3,44 \\
$\begin{array}{l}\text { Sukadana, } \\
\text { Bayan }\end{array}$ & 15 & 18,2 & 4,1 & 750,0 & 8,54 & 288,0 & 3,19 \\
$\begin{array}{l}\text { Akar-Akar, } \\
\text { Bayan } \\
\text { Malaka, }\end{array}$ & 12 & 19,0 & 4,9 & 1052,4 & 13,97 & 439,1 & 5,93 \\
Pemenang & 9 & 20,9 & 6,5 & 770,0 & 21,18 & 315,6 & 8,83 \\
\hline Jumlah & $\mathbf{6 2}$ & $\mathbf{7 5 , 8}$ & $\mathbf{2 0}$ & $\mathbf{2 5 7 2 , 4}$ & $\mathbf{5 2 , 5}$ & $\mathbf{1 3 9 7 , 7}$ & $\mathbf{2 1 , 4}$ \\
\hline Rerata & $\mathbf{1 5 , 5}$ & $\mathbf{1 8 , 9}$ & $\mathbf{5 , 0}$ & $\mathbf{6 4 3 , 1}$ & $\mathbf{1 3 , 1}$ & $\mathbf{3 4 9 , 4}$ & $\mathbf{5 , 3}$ \\
\hline
\end{tabular}

Keterangan (Remark) : N = Jumlah pohon model (Sample number), Dbh= Diameter setinggi dada (Diameter at breast height), Dt = Diameter tajuk(Crown diameter), $B B=$ Berat basah (Wet weight), $B K=$ Berat kering (Dryweight), $d p l=$ Diatas permukaan laut (Above sea level)

Pada kelompok mimba di Lombok Utara (Tabel 2), mimba yang berasal dari Desa Malaka Kecamatan Pemenang mempunyai biomassa daun yang paling besar $(8,83 \mathrm{~kg}$ per pohon). Berdasarkan penampilan individu pohon model, parameter-parameter pembentuk biomassa daun seperti diameter pohon, lebar tajuk dan jumlah ranting dari Desa Malaka Pemenang lebih unggul dari pada lokasi lain, kecuali tinggi pangkal tajuk. Jumlah ranting dari Pemenang (rata-rata 60 ranting) sangat jauh perbedaannya, yaitu rata-rata $50 \%$ dengan lokasi lain, yang mempunyai jumlah ranting rata-rata antara $26-34$ ranting. Sedangkan tinggi pangkal tajuk hanya $2,3 \mathrm{~m}$, lebih rendah dari lokasi-lokasi lain yang berkisar 4,2-4,8 m. Tempat tumbuh lokasi mimba mungkin juga berpengaruh, karena tanah di Desa Malaka relatif lebih subur ditinjau dari tekstur tanah.
Tekstur tanah lokasi mimba di Desa Malaka Pemenang lempung berpasir, Desa Anyar Bayan pasir berlempung, Desa Sukadana Bayan tekstur pasir, dan Desa Akar-Akar Bayan pasir berlempung (Lab. Tanah BPTP NTB, 2012).

Rata-rata penyusutan berat daun dari berat basah ke berat kering udara di Lombok Utara adalah sebesar kurang lebih $60 \%$. Relatif tidak ada penyusutan yang menonjol dari masing-masing lokasi, karena perbedaan tempat tumbuh mimba dengan tempat pengeringan relatif tidak jauh berbeda.

Berdasarkan hasil biomassa daun per pohon tersebut dapat ditentukan stok biomassa daun mimba yang tersedia di LombokLebih akuratnya di Lombok Utara dan Selatan, sebagai bahan baku obat-obatan dan pestisida nabati. Menurut Susila (2014), tanaman 
mimba banyak terdapat di Kabupaten Lombok Timur dan Lombok Utara. Stok biomassa daun mimba per kecamatan adalah Jerowaru 0,31 ton, Keruak 0,31 ton, Sakra 0,32 ton,
Pringgabaya 0,13 ton, Sambelia 0,13 ton dan Kecamatan Bayan 0,69 ton. Potensi tegakan dan stok daun mimba per kecamatan disajikan pada Gambar 1 .

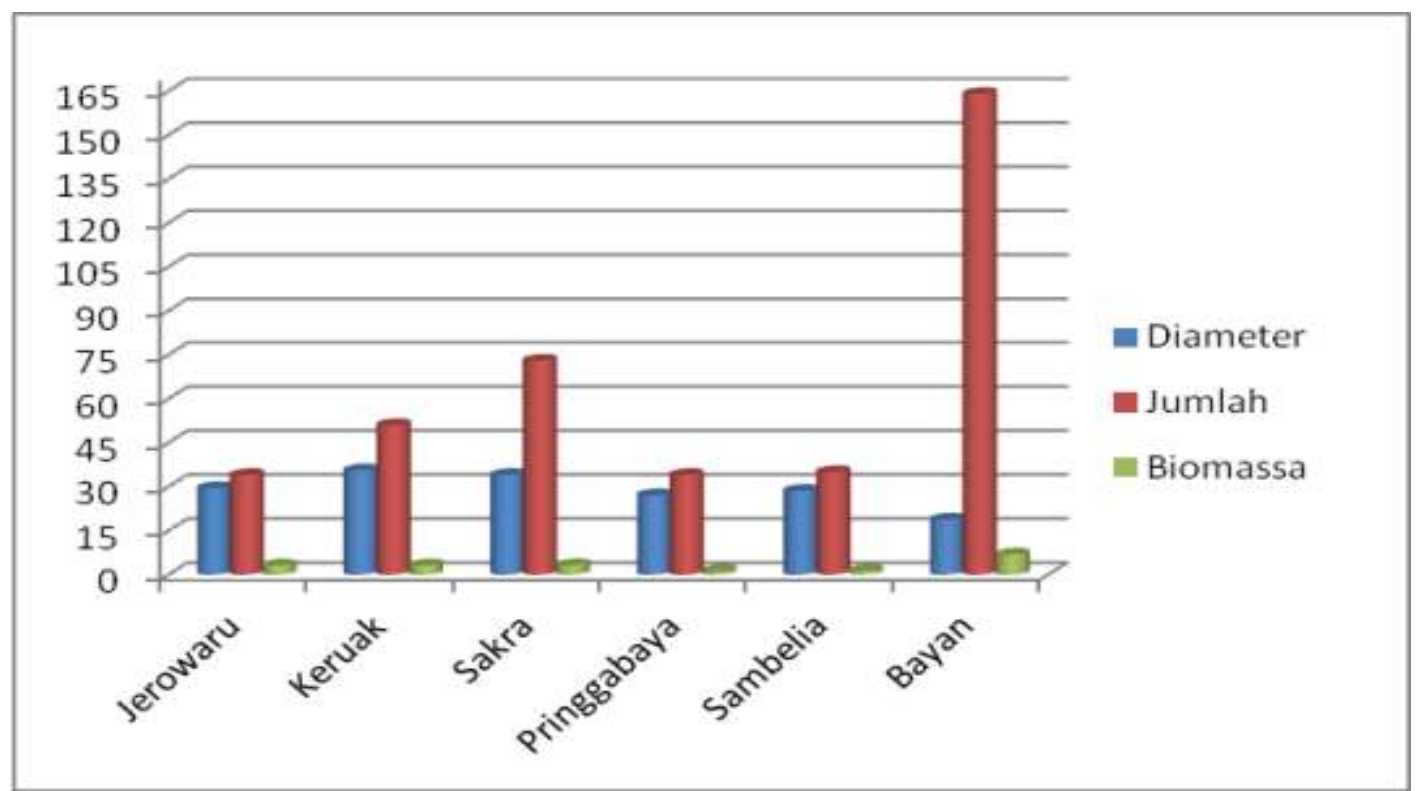

Keterangan (Remark) : cm untuk satuan diameter, pohon untuk satuan jumlah populasi, dan kwintal untuk biomassa; (cm for diameter unit, tree for the population number unit, and quintal for biomass Sumber (source) : Diolah dari Susila, 2014 (Adapted from Susila, 2014)

\section{Gambar 1. Potensi tegakan dan biomassa daun mimba per kecamatan Figure 1. Potential of Stands and Neem Leaf Biomass per Subdistrict}

Kebanyakan tanaman mimba dijumpai pada lahan-lahan milik sebagai pembatas kebun, yang kondisinya bukan sebagai tanaman dominan, bercampur dengan tanaman penghasil kayu (jati, mahoni, mindi, dll) dan tanaman serbaguna (mangga, jambu mente, kelapa dll). Tanaman mimba ditemukan dan tumbuh baik pada ketinggian kurang dari $100 \mathrm{~m}$ dpl di lahan-lahan kering dekat pantai. Sesuai dengan hasil pengamatan sebelumnya, bahwa tegakan mimba di Pulau Lombok pada umumnya ditemukan secara potensial di lahanlahan kering dataran rendah, umumnya dengan potensi air tanah yang rendah, dan menyebar memanjang sepanjang daerah sekitar pantai (Susila et al, 2014).

Pada Gambar 1 dapat dilihat bahwa sudah relatif langka menemukan pohon mimba berdiameter di atas $40 \mathrm{~cm}$ di Lombok, kemungkinan populasinya mengalami penurunan. Hal ini akan berpengaruh langsung dengan penurunan stok daun dimasa yang akan datang sebagai sumber bahan baku obatobatan. Aktifitas penebangan untuk pemenuhan kayu bakar maupun kayu pertukangan telah banyak dilakukan masyarakat sehingga menurunkan populasi mimba (Dinas Kehutanan NTB, 2008 \& Zaenal, 2007).

\section{Potensi Minyak Daun Mimba}

Hasil penyulingan daun mimba dan produksi minyak per pohon pada setiap pohon yang dijadikan sampel dapat dilihat pada Tabel 3 dan 4. 
Tabel 3. Produksi dan rendemen minyak per pohon di Lombok Timur Tablel 3. Production and rendement of neem oil per tree at East Lombok

\begin{tabular}{|c|c|c|c|c|}
\hline $\begin{array}{l}\text { No Pohon } \\
\text { (Tree) }\end{array}$ & $\begin{array}{c}\text { Berat Ekstrak } \\
(\text { Exract weight }) \\
(\mathrm{g})\end{array}$ & $\begin{array}{c}\text { Hasil Minyak } \\
\text { (Oil result) } \\
(\mathrm{g})\end{array}$ & $\begin{array}{c}\text { Rendemen } \\
\text { (Rendement) } \\
(\%)\end{array}$ & $\begin{array}{c}\text { Produksi Minyak } \\
\text { (Oil production) } \\
(\mathrm{kg})\end{array}$ \\
\hline 13 & 350 & 8,94 & 2,55 & 0,13 \\
\hline 6 & 490 & 8,99 & 1,83 & 0,07 \\
\hline 10 & 560 & 12,01 & 2,14 & 0,28 \\
\hline 15 & 900 & 13,67 & 1,52 & 0,40 \\
\hline 31 & 430 & 14,23 & 3,31 & 0,14 \\
\hline 32 & 540 & 13,98 & 2,59 & 0,15 \\
\hline 53 & 850 & 13,25 & 1,56 & 0,15 \\
\hline 54 & 600 & 11,48 & 1,91 & 0,17 \\
\hline 57 & 650 & 13,26 & 2,04 & 0,21 \\
\hline 58 & 720 & 8,32 & 1,16 & 0,08 \\
\hline 72 & 500 & 11,28 & 2,26 & 0,08 \\
\hline 73 & 320 & 12,88 & 4,03 & 0,09 \\
\hline 123 & 540 & 13,67 & 2,53 & 0,12 \\
\hline 140 & 570 & 8,39 & 1,47 & 0,04 \\
\hline 143 & 700 & 13,79 & 1,97 & 0,04 \\
\hline 144 & 620 & 12,89 & 2,08 & 0,15 \\
\hline 148 & 876 & 15,75 & 1,80 & 0,10 \\
\hline 151 & 680 & 13,05 & 1,92 & 0,19 \\
\hline 99 & 720 & 8,23 & 1,14 & 0,03 \\
\hline 104 & 380 & 9,26 & 2,44 & 0,13 \\
\hline 107 & 480 & 13,88 & 2,89 & 0,20 \\
\hline 120 & 750 & 8,93 & 1,19 & 0,06 \\
\hline 98 & 220 & 8,86 & 4,03 & 0,22 \\
\hline 195 & 460 & 8,80 & 1,91 & 0,02 \\
\hline 213 & 480 & 9,16 & 1,91 & 0,04 \\
\hline 215 & 420 & 9,85 & 2,35 & 0,07 \\
\hline 230 & 680 & 9,34 & 1,37 & 0,10 \\
\hline Rerata & 573,6 & 11,34 & 2,14 & 0,13 \\
\hline
\end{tabular}

Pada Tabel 3 terlihat bahwa kisaran rendemen minyak pada setiap pohon adalah $1,14-4,03 \%$. Berdasarkan lokasi tempat tumbuh mimba, rata-rata rendemen dan produksi minyak adalah di lokasi Jerowaru 2,3 $\%$ dan $0,20 \mathrm{~kg}$, Keruak 2,16 \% dan 0,13 kg, Sakra 1,94\% dan 0,11 kg, dan Sambelia 1,88\% dan $0,07 \mathrm{~kg}$. Perbedaan rendemen pada setiap lokasi kurang begitu menonjol, bahkan rendemen masing-masing pohon pada satu lokasipun terdapat perbedaan yang hampir sama, seperti mimba yang tumbuh di Jerowaru (nomor pohon 6-32). 
Hal ini menunjukan bahwa perbedaan tempat tumbuh mimba dalam penelitian ini tidak berpengaruh nyata terhadap rendemen minyak.

Dugaan awal perbedaan rendemen minyak dari daun mimba disebabkan oleh perbedaan kondisi daun, seperti daun tua dan daun muda. Namun dalam penelitian ini perbedaan umur daun, baik itu daun yang muda maupun yang tua tidak menunjukan perbedaan rendemen minyak yang konsisten. Oleh karena itu perlu dikaji lebih jauh untuk mengetahui faktor-faktor yang mempengaruhi rendemen minyaknya.

Tabel 4. Produksi dan rendemen minyak per pohon di Lombok Utara Tablel 4. Production and rendement of neem oil per tree at North Lombok

\begin{tabular}{|c|c|c|c|c|}
\hline $\begin{array}{l}\begin{array}{l}\text { No } \\
\text { Pohon } \\
\text { (Tree) }\end{array} \\
\end{array}$ & $\begin{array}{c}\text { Berat Ekstrak } \\
(\text { Exract weight }) \\
(\mathrm{g})\end{array}$ & $\begin{array}{c}\text { Hasil Minyak } \\
\text { (Oil result) } \\
(\mathrm{g})\end{array}$ & $\begin{array}{c}\text { Rendemen } \\
(\text { Rendement }) \\
(\%)\end{array}$ & $\begin{array}{c}\text { Produksi Minyak } \\
(\text { Oil production }) \\
(\mathrm{kg})\end{array}$ \\
\hline 354 & 300 & 10,28 & 3,43 & 0,11 \\
\hline 355 & 200 & 13,13 & 6,57 & 0,04 \\
\hline 357 & 250 & 14,54 & 5,82 & 0,12 \\
\hline 358 & 355 & 11,49 & 4,60 & 0,09 \\
\hline 370 & 357 & 9,15 & 3,66 & 0,15 \\
\hline 371 & 410 & 12,65 & 3,09 & 0,13 \\
\hline 366 & 560 & 6,72 & 1,20 & 0,11 \\
\hline 373 & 220 & 12,00 & 5,45 & 0,16 \\
\hline 329 & 480 & 16,19 & 3,37 & 0,17 \\
\hline 350 & 450 & 9,64 & 2,14 & 0,10 \\
\hline 340 & 270 & 15,56 & 5,76 & 0,74 \\
\hline 324 & 500 & 15,85 & 3,17 & 0,34 \\
\hline 377 & 210 & 10,36 & 4,93 & 0,11 \\
\hline 395 & 200 & 3,12 & 1,56 & 0,05 \\
\hline 388 & 330 & 7,43 & 2,25 & 0,10 \\
\hline 389 & 168 & 13,14 & 7,82 & 0,25 \\
\hline 391 & 270 & 9,06 & 3,36 & 0,15 \\
\hline 386 & 760 & 16,61 & 2,19 & 0,08 \\
\hline 384 & 300 & 11,76 & 3,92 & 0,17 \\
\hline 398 & 110 & 10,48 & 9,53 & 0,32 \\
\hline 397 & 230 & 9,35 & 4,07 & 0,06 \\
\hline 466 & 480 & 11,54 & 2,40 & 0,16 \\
\hline 452 & 480 & 4,23 & 0,88 & 0,08 \\
\hline 458 & 450 & 9,63 & 2,14 & 0,16 \\
\hline 461 & 420 & 13,36 & 3,18 & 0,15 \\
\hline 401 & 410 & 8,07 & 1,97 & 0,12 \\
\hline 426 & 370 & 14,95 & 4,04 & 0,11 \\
\hline 418 & 560 & 8,18 & 1,46 & 0,03 \\
\hline 415 & 520 & 12,73 & 2,45 & 0,15 \\
\hline 411 & 950 & 11,50 & 1,21 & 0,08 \\
\hline 472 & 850 & 16,36 & 1,92 & 0,38 \\
\hline Rerata & 393,8 & 11,26 & 3,53 & 0,16 \\
\hline
\end{tabular}

Pada Tabel 4 dapat dilihat bahwa kisaran rendemen minyak pada setiap pohon adalah
$0,88-9,53 \%$, lebih fluktuatif dibandingkan dengan hasil rendemen minyak dari Lombok 
Timur. Berdasarkan dari lokasi tempat tumbuh tanaman mimba di Lombok Utara, rata-rata rendemen dan produksi minyak mimba adalah di Desa Anyar 4,1 \% dan 0,18 kg, Sukadana 4,34 \% dan 0,15 kg, dan Desa Akar-Akar 2,17 $\%$ dan $0,14 \mathrm{~kg}$. Rata-rata rendemen minyak dari Lombok Utara lebih besar dari pada Lombok Timur. Perbedaan rendemen ini kemungkinan karena dominan pengaruh tempat tumbuh (site), seperti ketinggian tempat yang berpengaruh pada kelembaban (kadar air), kesuburan tanah (kandungan unsur-unsur makro dan mikro) dan iklim/cuaca saat pengumpulan daun.

\section{C.Faktor-Faktor Yang Berpengaruh Terhadap Potensi Daun}

Uji korelasi antar dan inter variabel dilakukan untuk mengetahui keeratan hubungan sebagai dasar untuk memprediksi potensi daun dengan bantuan program statistik SPSS 18,0 (Elcom, 2010). Variabel tak bebas yang digunakan adalah berat basah total daun per pohon $(B b t d)$, sedangkan untuk variabel bebas adalah diameter pohon $(d b h)$, lebar tajuk $\left(l_{-} t j k\right)$, tinggi pohon $\left(t \_p h n\right)$, tinggi pangkal tajuk (t_ptjk),jumlah cabang $\left(j \_c b\right)$, dan jumlah ranting (j_rt). Hasil uji korelasi disajikan pada Tabel 5.

Tabel 5. Koefesien korelasi antar seluruh variabel Tablel 5. Correlation coefficient between all variables

\begin{tabular}{|c|c|c|c|c|c|c|c|c|c|}
\hline & dbh & I_tjk & t_phn & t_ptjk & j_cb & j_rt & Bbtd & alt & pH \\
\hline dbh & 1 & $0,756^{* *}$ & $0,250^{*}$ & $-0,047$ & $0,512 * *$ & $0,644^{* *}$ & $0,428^{* *}$ & $-0,186$ & 0,307 ** \\
\hline l_tjkk & $0,756^{* *}$ & 1 & 0,160 & $-0,193$ & $0,556^{* *}$ & $0,708^{* *}$ & $0,529 * *$ & $-0,135$ & $0,363^{* *}$ \\
\hline t_phn & $0,250 *$ & 0,160 & 1 & $0,639 * *$ & 0,032 & 0,121 & 0,093 & $-0,141$ & $-0,135$ \\
\hline t_ptjk & $-0,047$ & $-0,193$ & $0,639 * *$ & 1 & $-0,181$ & $-0,271 * *$ & $-0,183$ & $-0,072$ & $-0,273 * *$ \\
\hline j_cb & $0,512 * *$ & $0,556^{* *}$ & 0,032 & $-0,181$ & 1 & $0,734 * *$ & $0,384 * *$ & 0,072 & 0,184 \\
\hline j_rt & $0,644 * *$ & $0,708 * *$ & 0,121 & $-0,271 * *$ & $0,734 * *$ & 1 & $0,568 * *$ & $-0,178$ & $0,345^{* *}$ \\
\hline Bbtd & $0,428 * *$ & $0,529 * *$ & 0,093 & $-0,183$ & $0,384 * *$ & $0,568^{* *}$ & 1 & $-0,156$ & 0,174 \\
\hline alt & $-0,186$ & $-0,135$ & $-0,141$ & $-0,072$ & 0,072 & $-0,178$ & $-0,156$ & 1 & $-0,113$ \\
\hline pH & $0,307^{* *}$ & $0,363^{* *}$ & $-0,135$ & $-0,273 * *$ & 0,184 & $0,345^{* *}$ & 0,174 & $-0,113$ & 1 \\
\hline
\end{tabular}

Keterangan (Remark): **Correlation is significant at the 0.01 level.

* Correlation is significant at the 0.05 level

Pada Tabel 5 dapat dilihat bahwa ada empat variabel bebas yang berpengaruh signifikan terhadap produksi daun mimba yaitu diameter pohon, lebar tajuk, jumlah cabang dan jumlah ranting, sedangkan faktor variabel lingkungan, yaitu tinggi tempat (altitude) dan tingkat kesuburan tanah $(p H)$ kurang berpengaruh. Variabel jumlah ranting mempunyai korelasi yang paling tinggi, kemudian secara berurutan adalah lebar tajuk, diameter pohon dan jumlah cabang. Hal ini sesuai dengan hasil penelitian nyamplung (Calophyllum inophyllum Linn) di Bali dan NTB, bahwa produksi buah nyamplung sangat dipengaruhi oleh faktor ukuran dimensi pohon seperti diameter dan lebar tajuk, sedangkan faktor tempat tumbuh kurang berpengaruh (Susila dan Handoko, 2015). Menurut Foster (2008) bahwa produksi buah yang banyak (abundance) berkorelasi dengan ukuran tajuk pohon dan kerapatan tajuk (foliage density), termasuk kerapatan cabang dan ranting.

Berdasarkan hasil korelasi tersebut dicoba dikaji model estimasi potensi daun mimba disusun berdasarkan sebaran mimba di Lombok. Tahap awal, menggunakan satu variabel bebas untuk memprediksi potensi daun per pohon. Beberapa bentuk model 
regresi yang dikaji adalah model linear $(P=a+$ $b X)$, model logharitma $(P=\log a+b \ln X)$, model kuadratik $\left(P=a+b X+c X^{2}\right)$, model power $\left(P=a X^{b}\right)$ dan model exponentia $(P=a$ $\left.e^{b x}\right)$, dimana ? adalah potensi daun, $X$ adalah parameter tertentu sebagai peubah bebas. Huruf $a, b$, dan $c$ adalah konstanta, dan $e=$
2,7183 (Gomez, et al., 1995, Simon, 2007). Model terbaik pada setiap variabel bebas dikaji melaui nilai $R$-square $\left(r^{2}\right)$, standard error dan kemudahan tingkat aplikasi model. Model persamaan regresi terbaik untuk menentukan produksi daun (berat basah daun/bbtd) pada setiap variabel bebas ditampilkan pada Tabel 6 .

Tabel 6. Model-model terbaik produk daun pada setiap variabel Tablel 6. The best models of leaf product on every variable

\begin{tabular}{|c|c|c|c|c|c|}
\hline No. & $\begin{array}{c}\text { Variabel } \\
\text { (Variables) }\end{array}$ & $\begin{array}{c}\text { Model Regresi } \\
\text { (Regression models) }\end{array}$ & $\begin{array}{c}R \text {-square } \\
(\%)\end{array}$ & $\mathrm{Se}(\%)$ & Sig \\
\hline 1 & Diameter & Bbtd $=0,337 \mathrm{dbh}^{1,088}$ & 21,6 & 5,45 & 0,000 \\
\hline 2 & Lebar tajuk & Bbtd $=1,3701 \_t \mathrm{tjk}^{1,116}$ & 33,5 & 5,02 & 0,000 \\
\hline 3 & Tinggi pohon & $\mathrm{Bbtd}=5,728 \mathrm{t} \_$phn ${ }^{0,186}$ & 0,4 & 6,14 & 0,554 \\
\hline 4 & $\begin{array}{l}\text { Tinggi pangkal } \\
\text { taiuk }\end{array}$ & Bbtd $=14,697 \mathrm{t} \_p t j k^{-0,384}$ & 4,1 & 6,03 & 0,044 \\
\hline 5 & Jumlah cabang & $\operatorname{Bbtd}=3,735$ j_cb $b^{0,576}$ & 21,5 & 5,45 & 0,000 \\
\hline 6 & Jumlah ranting & $\mathrm{Bbtd}=0,823 \mathrm{j} \mathrm{rt}^{0,650}$ & 41,9 & 4,69 & 0,000 \\
\hline
\end{tabular}

Pada Tabel 6 terlihat bahwa dari enam variabel bebas yang dicoba menghasilkan model persamaan regresi terbaik yaitu model power, ditinjau dari nilai koefesien determinasi $(R$ square) dan kesalahan baku (Se) yang dihasilkan. Model-model terpilih tersebut memenuhi persyaratan untuk menduga produksi daun mimba sesuai yang diperkenankan. Menurut Prodan (1965) dalam Hardjana (2013), dalam menyusun model berdasarkan persamaan regresi yang menggunakan satu peubah diperkenankan kesalahan baku $(\mathrm{Se})$ maksimal $25 \%$. Pada model nomor 3 hasilnya kurang signifikan pada taraf kepercayaan $95 \%$.

Berdasarkan $R$-square dan $\mathrm{Se}$, model nomor 6 dengan variabel jumlah ranting adalah model terbaik untuk menentukan potensi daun mimba. Hal ini sesuai dengan nilai koefesien korelasi yang tertinggi pada hubungan kedua variabel tersebut (Tabel 5). Model regresi power paling banyak ditemukan dan digunakan untuk menduga volume pohon berdiri $(V)$ dengan satu variabel diameter $(D)$, yaitu $V=a D^{b}$ (Muhdin, 2003), karena alasan kesederhanaan dan kepraktisan model. Hasil penelitian seperti model $V=a D^{b}$ didukung juga oleh hasil-hasil penelitian pada jenis-jenis hutan tanaman di dalam kawasan hutan, yaitu jenis Acacia mangium sampai ketinggian pohon pada diameter batang $7 \mathrm{~cm}\left(V_{7}\right) \mathrm{di}$ Balikpapan 0,000793 D1,8873 (Bustomi, 1988), jenis damar (Agathis loranthifolia) di Banyumas $V 7=0,000142$ D2,4546 (Siswanto dan Krisnawati, 1998), dan jenis Eucalyptus deglupta sampai tinggi pohon bebas cabang $\left(V_{b c}\right)$ di Sulawei Selatan $=0,000257$ D2,2563 (Siswanto dan Suyat, 2006).

Satu parameter jumlah ranting berpengaruh maksimal sampai $42 \%$ terhadap potensi daun mimba, lebih dari $58 \%$ dipengaruhi oleh variabel yang lain (lihat Tabel 5). Selain kombinasi faktor variabel internal seperti tersebut di atas, besaran potensi daun juga dipengaruhi oleh faktor eksternal seperti lingkungan (tempat tumbuh/site dan tinggi 
tempat). Dalam hal ini, tempat tumbuh (tingkat kesuburan) diwakili oleh $\mathrm{pH}$ tanah dan tinggi tempat oleh elevasi (alt). Oleh karena itu, untuk menduga potensi daun mimba tidak cukup hanya satu parameter saja, melainkan beberapa parameter yang berpengaruh terhadap potensi daun.

Dalam penyusunan persamaan linear pendugaan potensi daun dengan menggunakan dua atau lebih variabel bebas. Parameter pertama yang dipilih adalah diameter atau lebar tajuk karena mempunyai tingkat kesulitan pengukuran relatif paling rendah, kemudian parameter berikutnya dipilih variabel bebas yang mempunyai korelasi tidak signifikan dengan variabel bebas yang digunakan sebelumnya. Penggunaan variabel-variabel yang saling berpengaruh (signifikan) kurang meningkatkan $R$-Square model yang dihasilkan. Oleh karena itu, berdasarkan Tabel 5 akan dicoba beberapa model dengan susunan variabel bebas seperti pada Tabel 7 .

Tabel 7. Model-model penduga produk daun dengan dua atau lebih variabel bebas Tablel 7. The estimation models of leaf product with two or more free variables

\begin{tabular}{|c|c|c|c|c|c|}
\hline No. & $\begin{array}{c}\text { Variabel } \\
\text { (Variables) }\end{array}$ & $\begin{array}{c}\text { Model Regresi } \\
(\text { Regression models }) \\
\end{array}$ & $\begin{array}{c}R \text {-square } \\
(\%)\end{array}$ & $\mathrm{Se}(\%)$ & Sig \\
\hline \multirow[t]{2}{*}{1.} & \multirow{2}{*}{$\begin{array}{l}\text { Diameter, lebar } \\
\text { tajuk }\end{array}$} & $\begin{array}{c}\text { a. Bbtd }=-0,100+0,025 \mathrm{dbh}+ \\
0,7461 \_ \text {tjk }\end{array}$ & 26,3 & 24,00 & 0,000 \\
\hline & & b. Bbtd $=1,132 \mathrm{dbh}^{0,098} 1 \mathrm{tjk}^{1,055}$ & 33,5 & 2,19 & 0,000 \\
\hline \multirow{2}{*}{2.} & \multirow{2}{*}{$\begin{array}{l}\text { Diameter, tinggi } \\
\text { pangkal tajuk, } \\
\text { altitude }\end{array}$} & $\begin{array}{r}\text { a. Bbtd }=4,472+0,522 \mathrm{dbh}- \\
0,856 \mathrm{t} \_p t j \mathrm{k}-0,032 \text { alt }\end{array}$ & 21,8 & 62,11 & 0,000 \\
\hline & & $\begin{array}{c}\text { b. Bbtd }=1,273 \mathrm{dbh}^{1,027} \mathrm{t} \_\mathrm{ptjk} \\
\text { alt }^{-0,183}\end{array}$ & 28,0 & 2,29 & 0,000 \\
\hline \multirow{2}{*}{3.} & \multirow{2}{*}{$\begin{array}{l}\text { Lebar tajuk, } \\
\text { tinggi pohon, } \\
\text { altitude }\end{array}$} & $\begin{array}{c}\text { a. Bbtd }=0,532+2,03011 \mathrm{tjk}- \\
0,007 \mathrm{t} \_ \text {phn }-0,029 \text { alt }\end{array}$ & 28,7 & 59,30 & 0,000 \\
\hline & & 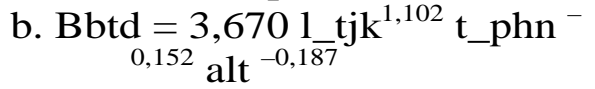 & 36,1 & 2,16 & 0,000 \\
\hline \multirow{2}{*}{4.} & \multirow{2}{*}{$\begin{array}{l}\text { Jumlah ranting, } \\
\text { Tinggi pohon, } \\
\text { altitude }\end{array}$} & $\begin{array}{c}\text { a. Bbtd }=4,687+0,131 \text { j_rt }+ \\
0,060 \text { t_phn-0,018 alt }\end{array}$ & 32,7 & 57,64 & 0,000 \\
\hline & & b. Bbtd $=1,845 \underset{0,093}{\text { alt }^{-0,168}} \mathrm{j}^{\mathrm{rt}^{0,638}} \mathrm{t} \_\mathrm{phn}^{-}$ & 44,0 & 2,03 & 0,000 \\
\hline
\end{tabular}

Pada Tabel 7 terlihat bahwa dengan menggunakan model linear berganda, nilai kesalahan bakunya ( $\mathrm{Se}$ ) melebihi persyaratan yang diperkenankan oleh Prodan (1965) dalam Hardjana (2013), yaitu lebih dari $20 \%$. Untuk mensiasatinya dicoba melakukan transpormasi data dengan cara log semua data dan dianalisis dengan model yang sama (model linear berganda) sehingga terjadi perubahan persamaan regresi, yaitu $\log (y)=\log (\beta 0)+\beta 1$ $\log (x 1)+\beta 2 \log (x 2)+\cdots+\beta m \log (x m)+$ $\log (\varepsilon)$ (Freund et al., 2006). Model ini dalam penulisannya bisa berubah menjadi model power yang hasilnya disajikan pada Tabel 7 (b). Semua model ini dengan berbagai variabel bebasnya mempunyai kesalahan baku yang relatif sangat rendah, kurang dari $3 \%$.

Penggunaan variabel bebas lebih dari satu untuk pendugaan potensi daun mimba hanya dapat meningkatkan $R$-Square sampai $44,0 \%$, kurang lebih $56 \%$ dipengaruhi oleh faktor lain (selain jumlah ranting, tinggi pohon dan elevasi). $R$-Square dapat ditingkatkan dengan mencoba menggunakan semua variabel 
bebas pada Tabel 5, yaitu menggunakan semua variabel dimensi pohon (faktor intern enam variabel) diperoleh $R$-Square 44,4 \% dan faktor lingkungan (elevasi dan $p H$ tanah) menjadi delapan variabel diperoleh $R$-Square 48,9\%. Hal ini berarti lebih dari $50 \%$ masih terdapat variabel lain yang berpengaruh dan belum teridentifikasi terhadap potensi daun mimba. Kemungkinan variabel-variabel lain tersebut adalah variasi ukuran keliling dan panjang ranting, variasi kerapatan daun dalam ranting, variasi ketebalan daun, warna daun, variasi ukuran daun, dan lain sebagainya. Faktor lain yang kemungkinan berpengaruh adalah kerapatan tegakan, faktor dominasi, faktor gangguan tanaman (pruning/ pemangkasan daun).

\section{KESIMPULANDAN SARAN}

\section{A. Kesimpulan}

Potensi daun mimba per pohon di Lombok Timur adalah 7,4 - 21,6 kg, kandungan minyak dan rendemennya 0,07 $0,20 \mathrm{~kg}$ dan 1,88 - 2,33 \%. Di Lombok Utara potensi daun, kandungan minyak dan rendemennya adalah $8,5-21,2 \mathrm{~kg}$ per pohon, $0,14-0,18 \mathrm{~kg}$ per pohon dan $2,17-4,34 \%$. Stok biomassa daun mimba per kecamatan adalah Jerowaru 0,31 ton, Keruak 0,31 ton, Sakra 0,32 ton, Pringgabaya 0,13 ton, Sambelia 0,13 ton dan Kecamatan Bayan 0,69 ton.

Berdasarkan koefesien korelasi, urutan variabel yang sangat berpengaruh terhadap potensi daun adalah jumlah ranting, jumlah cabang, lebar tajuk dan diameter pohon. Penggunaan parameter jumlah ranting memberikan persamaan regresi terbaik untuk menduga potensi daun mimba, yaitu $B b t d=$ $0,823 j{ }_{-} r t^{0,650}$ dengan koefesien determinasi $41,9 \%$ dan kesalahan baku 4,69\%. Penggunaan seluruh variabel yang teridentifikasi seperti diameter, tajuk dan tempat tumbuh dengan model regresi linear berganda diperoleh koefesien determinasi $48,9 \%$. Berarti ada variabel lain yang belum teridentifikasi yang berpengaruh terhadap potensi daun mimba sebesar lebih dari $50 \%$.

\section{B.Saran}

Untuk meningkatkan koefesien determinasi (R-Square) model estimasi produksi daun mimba dapat dilakukan dengan mengidentifikasi variabel bebas lain, menambah sampel dan pengulangan waktu pengumpulan daun pada berbagai kondisi iklim.

\section{UCAPAN TERIMA KASIH}

Penulis mengucapkan terima kasih kepada semua pihak yang telah memfasilitasi dan terlibat dalam penelitian ini, yaitu Kepala Balai Peneltian Teknologi HHBK, Kepala dan staf UPTD Kehutanan dan Perkebunan Kecamatan Keruak dan jerowaru, Kecamatan Pringgabaya dan Suwela, Kabupaten Lombok Timur.

\section{DAFTAR PUSTAKA}

Anshori, J.A dan Hidayat, A.T. 2009. Konsep Dasar Penyulingan dan Analisa Sederhana Minyak Nilam. Lembaga Penelitian dan Pengabdian pada Masyarakat Universitas Padjadjaran. Bandung.

Aradilla, A.S. 2009. Uji Efektivitas Larvasida Ekstrak Ethanol Daun Mimba (Azadirachta indica A. Juss) terhadap Larva Aedes aegypti. Laporan Akhir Penelitian. Fakultas Kedokteran Universitas Diponegoro. Semarang. http://eprints.undip.ac.id.

Bustomi, S. 1988. Tabel isi pohon lokal Acacia mangium untuk daerah Balikpapan. Bul. Pen. Hutan No 495:31-38. Pusat Litbang Hutan Bogor. Bogor.

Bustomi, S, Harbagung, dan Suyat, 2005. Petunjuk Teknis Penyusunan Tabel Volume Pohon. Pusat Litbang Hutan Konservasi Alam. Bogor.

Dinas Kehutanan NTB, 2008. Statistik Kehutanan Provinsi Nusa Tenggara Barat Tahun 2007. Dinas Kehutanan Provinsi Nusa Tenggara Barat. Mataram.

Foster, M.S. 2008. Freeze-frame fruit selection by birds. The Wilson Journal of Ornithology 120 (4) : 901-905. 
Freund Rudolf J., William J. Wilson, Ping Sa. 2006. Regression Analysis: Statistical Modeling of a Response Variable.-2nd ed. Academic Press is an imprint of Elsevier.

Gomez, K. A and Gomez, A.A. 1995. Prosedur Statistik Untuk Penelitian Pertanian (terjemahan). Universitas Indonesia. Jakarta.

Hardjana, A. K. 2013. Model Hubungan Tinggi dan Diameter Tajuk dengan Diameter Setinggi Dada pada Tegakan Tengkawang Tungkul Putih (Shorea macrophylla (de Vriese) P.S. Ashton) dan Tungkul Merah (Shorea stenoptera Burck.) di Semboja, Kabupaten Sanggau. Jurnal Penelitian Dipterocarpa, Vol 7 Nomor 1, Hal 6 - 17. Balai Besar Penelitian Dipterocarpa. Samarinda.

Hutabarat, C., Yanti dan Dwinardi. 2012. Fikasi Ekstrak Campuran Daun Mimba (Azadirachta indica A. Juss) dan Kwalot (Brucea javanica L. Merr) terhadap Penggerek Polong (Etiella zinckenella) pada Tanaman Kacang Tanah dan Kedelai. Thesis. Fakultas Pertanian UNIB. http://repository.unib.ac.id, 21 Pebruari 2014.

Elcom. 2010. SPSS 18 : Statistik deskriptif, Tabulasi silang dan korelasi, mean, transformasi data, analisis varian, analisis regresi. CV. Andi offset. Yogyakarta.

Lab. Tanah BPTP NTB. 2012. Laporan Hasil Uji 5 contoh tanah dari Kab Lombok Timur dan Lombok Utara. Laboratorium Pengujian BPTPNTB. Mataram.

Muhdin.2003. Dimensi Pohon dan Perkembangan Metode Pendugaan Volume Pohon. Pengantar Falsafah Sains. Program Pasca Sarjana, Institut Pertanian Bogor. Bogor.

Nurhasybi dan D.J. Sudradjat. 2009. Teknik Pendugaan Potensi Produksi Benih Tanaman Hutan. Info Benih Volume II, No. 1. Puslitbang Hutan Tanaman. Bogor.

Simon, H. 2007. Metode Inventore Hutan. Pustaka Pelajar. Yogyakarta.
Siswanto, B.E. dan Krisnawati, H. 1998. Tarif isi pohon untuk Agathis loranthifolia Salisb. di Kesatuan Pemangkuan Hutan Banyumas Barat, Jawa Tengah. Bul. Pen. Hutan No.515:1-7. Pusat Litbang Hutan, Bogor.

Siswanto, B.E., Suyat. 2006. Model pendugaan isi pohon jenis Eucalyptus deglupta Blume. Di Borisalo, Sulawesi Selatan. Jurnal Penelitian Hutan dan Konservasi Alam Vol I No 2: 139-146. Bogor : Pusat Litbang Hutan dan Konservasi Alam.

Susila, IWW. 2014. Potensi Mimba sebagai Bahan Baku Produk Kesehatan dan Pertanian di Bali dan Lombok. Makalah disampaikan pada Seminar Nasional Hasil Penelitian HHBK, Tanggal 04 Desember 2014 di Mataram. Kerjasama Balai Penelitian Teknologi HHBK, Fak Ilmu Kehutanan UNTB dan Program Studi Kehutanan Universitas Mataram. Mataram.

Susila, IWW. dan Handoko, C. 2015. Tempat Tumbuh dan Faktor-Faktor Yang Mempengaruhi Potensi Buah Nyamplung (Calophyllum inophyllum Linn) di Nusa Tenggara Barat dan Bali. Prosiding Seminar Nasional Sewindu BPTHHBK Mataram. Hal 250-261. Badan Litbang dan Inovasi, Balai Penelitian Teknologi Hasil Hutan Bukan Kayu. Mataram.

Susila, IWW., Cakrawarsa, G., Handoko, C. 2014. Potensi dan Tata Niaga Mimba (Azadirachta indica A.Juss) di Lombok. Jurnal Penelitian Hutan Tanaman, Vol. 11 No. 2, hal. 123 - 135. Pusat Litbang Peningkatan Produktivitas Hutan. Bogor.

$\mathrm{Z}$ a enal, B. 2007. Pengalaman Menyelenggarakan Hutan Kemasyarakatan (HKm) di Propinsi Nusa Tenggara Barat (NTB). Bahan Masukan dalam Kegiatan Konsultasi Publik Draft Permenhut tentang HKM dan Hutan Desa, 20 Juni 2007. Dinas Kehutanan Propinsi NTB. Mataram.

Www. Flu.org.cn/en/download - 79. Htnl. 2008. Curve Expert 1.3. Diakses tanggal 7 September 2008. 
Jurnal FALOAK Vol.1 No. 2 Oktober 2017: 85-98 